\title{
THE APPLICATION OF THINK-TALK-WRITE STRATEGY TO IMPROVE THE TENTH GRADE OF SMA SANTO YOSEPH MEDAN STUDENTS' SKILL IN WRITING RECOUNT TEXT
}

\author{
Tio Devianta br Sembiring, Novalina Sembiring, Fiber Yun A. Ginting \\ Catholic University of Saint Thomas \\ Email : novalina_sembiring@ust.ac.id
}

\begin{abstract}
The aim of this study is to find whether Think - Talk - Write Strategy works effectively on improving the tenth grade students' achievement in writing recount texts and to know the students' responses after being taught by using Think - Talk - Write Strategy . in order to achieve the objectives of study, a classroom action research was designed and carried out in this study. The subjects of this study were 32 students of class X- MIA ${ }^{2}$ OF SMA Santo Yoseph Medan in academic year 2018/2019. Test, observation sheet, and field notes were used as a instruments for collecting data. The results of the study showed significant improvement of the students' skill in writing. It is proved by the students' mean score of each test: pretest was $57,5 \%$, formative test was $67,22 \%$ and post-test was $83,88 \%$. In addition, the, the analysis result of the observation sheet and field notes showed Think-Talk - Write Strategy channge the students' learning behavior being better than before. They were more enthusiastic during the teaching learning process in each cycle. The analysis result of questionnaire showed that Think - Talk-Write Strategy was useful to most of students to improve their learnig interest in writing recount text. Based on the results of those study instruments, it can be concluded that ThinkTalk - Write Strategy as learning strategy gives the improvement to students' skill in writing recount text. It is recommended for English teacher to apply Think-Talk - Write Strategy in teaching writing skill in order to improve students' skill in writing expecially recount text.
\end{abstract}

Keywords: Writing Skill, Recount Texts and Think - Talk - Write Strategy

\section{INTRODUCTION}

There are four language skills that include in the curiculum of teaching English as a foreign language namely listening, speaking, reading, and writing. One of these four skills which is important and required in academic is writing. There are many diffrences between the process of speaking and writing. Writing is not simply speech written down on paper. Learning to write is not natural extention of learning to speak. Unlike speech, writing requires systematic instruction and practice. Writing is a learning process that is only taught in a formal education not the same as speaking that can be learned in the environment. Written language is more restricted and generally follows a standardised form of grammar, structure, organization, and vocabulary and most writing is planned and can be changed through editing and revision before an audience reads it but speaking is often spontaneous and unplanned. Through writing people can share their knowledge, ideas or mind in written text to everyone who wants to read it. Writing is a process of thinking, organizing, rethinking, and reorganizing. The mastery of vocabulary,

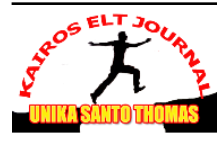


spelling, grammar, punctuation are required in writing. However the ability of thinking and the ability of organizing are more crucial so that the writer can express his idea in sentences which have good coherence.

Harmer (1998:84) states that writing is very complex because it is not as easy as spontaneous activity. It means writing is viewed as a difficult skill by almost all students because they must transfer their idea properly, naturally as well as interestingly. This is the reason why many people and students find it difficult to write.Therefore, in order to achieve the goal of teaching writing, teachers have to know the students' difficulty in writing. By doing so, they could help the students to solve their problems.

Based on the writer's experience when having Teaching Practice Program at SMA Santo Yoseph Medan, most of the students were not able to write recount texts successfully. It could be seen from their score when they were doing exercises. Some of them got score below Minimum Mastery Criteria (Kriteria Ketuntasan Minimal/KKM). Therefore they had to do remedial test. When students get low score in writing recount text, it means that students' achievement in writing recount text must be improved because if the students' achievement is not improved, students will fail in their academic performance and that is a serious problem. It shows that the quality of English writing in the school is poor especially in writing recount text.

Recount text is a text which retells events or experiences in the past. Its purpose is to inform or to entertain the audience. Writing recount text actually is not difficult, but many students can not develop their idea. They do not know what should they write and it makes them confused.

Considering the gap between the reality and expectation, the writer is interested in giving a probable solution. To teach writing skill, teachers should use many kinds of ways in order to make students master the lesson. Various ways have been used as the methods of teaching writing skill to make writing easier to be understood. However, the students' ability in writing skill is not yet satisfactory. One of strategies which is suitable in teaching writing is Think - Talk - Write (henceforth, TTW) strategy. TTW strategy is believed to be able to stimulate and guide the students to write. TTW strategy is seen as an active learning process because the students will learn more through thinking, discussion, and then make a note about the result of discussion. It means that students will express the result of discussing in their own group and in the form of written text.

The writer also chooses this strategy because some research findings have shown the good results of teaching writing skill by using TTW strategy especially in Recount text. The first research was conducted by Astuti (2014) entitled 'Improving Students' Writing Skill of Recount Texts by Using Think - Talk - Write Strategy at Grade VIII-B of MTS SMQ Bangko. The research findings showed that students' writing skill improved after patterns of TTW strategy was applied. The mean score of the students in the pre test is 66.78. After patterns of TTW strategy was applied, the mean score of the students became 69.61 in the post test cycle I and in the post test cyle II the mean score of the students became 72.04.

The second one was conducted by Waryanti (2016) entitled "The Implementation of Think - Talk - Write Strategy to Improve the Students' Achievement in Writing Recount Texts among the Eighth Grade Students of SMP Negeri 1 Wates in the Academic Year 2016/2017'. The research findings showed

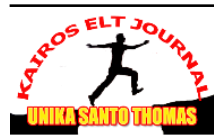


that students' writing skill improved after patterns of TTW strategy was applied. The mean score of the students in the pre test is 64.77. After patterns of TTW strategy was applied the mean score of the students became 85.77 in the post test cycle I and in the post test cycle II the mean score of the students became 87.27. The result shows that there is a significant improvement of using TTW strategy on students' writing skill. From the previous researches the writer can conclude that students' writing skill improves by applying TTW strategy.

Based on the background of the study, the writer is interested in conducting a research entitled "The Application of Think - Talk - Write Strategy to Improve Students' Skill in Writing Recount Texts".

\section{REVIEW OF LITERATURE Writing}

Writing is very useful to produce written messages. When we write, we have the purpose why we write it. According to Hyland (2002:1)writing is the centre of our personal experience and social identities, and we are often evaluated by our control of it. Menwhile, Heaton (1988:135) states that writing is the ability to use structure. Writing refers to the skill using graphic symbols that have to be arranged based on certain conventions. It means that writing is the act of the skill informing graphic symbols and combining a number of diverse elements. It is in line with Brown (2001:337) who points out that writing is a way to end up thinking which is characterized by the ability to record and process what we get on our mind.

From the definitions above, it can be concluded that writing is process of discovering and organizing the ideas, about how to express them and organize them into statement and paragraph that will be clear to a reader. Writing should communicate the ideas clearly, precisely as well as and unambiguously so that the readers can comprehend what the writer meant. Since the writer is absent, he can not be asked if there is something unclear in writing.

\section{The Process of Writing}

A good writing is a result of acomplete process of writing. When the writer obeys the rule of writing and follows the steps of the writing proces, he can produce a good writing. Harmer (2004:4-5) states that writing process has the stages to produce something. There are at least four stages in the process of writing:

a. Planning

In this stage, the writer considers three aspects of planning. First aspect is purpose. The writer gives attention to the information that he or she selects. Second, the writer has to know for whom he or she writes. The writing influences the thinking of audience. Third, the writer pays attention on the content structure while he is writing. He or she has to design the organization well including facts, ideas, or opinions.

b. Drafting

In this stage, the writer should have final writing before it is going to be edited. Correcting is done in the next stages after drafting.

c. Editing

In this stage, the writer reflects and revises the final writing after it was edited. This stage is helped by editor (reader) who gives opinions and suggestions of final writing.

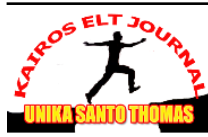




\section{d. Final draft}

Final draft is the last process of writing. It is the result of writing process through three previous stages.

It can be condluded the writershould pass the steps, such as planning (explore ideas, pre-write, organize), drafting, editing, finaling draft and producing the final copy. The students will be able to create a good writing by following the stages in the process of writing

\section{The Assessment of Writing}

In order to evaluate the students' mastery in writing skill, the teacher has to get the right concept of writing assessment to assess the students' writing work appropriately. According to Hughey et al. (1983: 141-145), there are five components in writing assessment:

a. Content

Content of writing covers clear main idea, detailed and substantiveall materials are relevant to main idea. The writer must exclude everything irrelevant to main idea to reach exellent level of content of writing.

b. Organization

A writer is expected to demonstrate an understanding that each paragraph contains a topic sentence and that all other sentences in the paragraph related to that topic. Understanding of cohesion involves relationship between clauses and sentences by means of linking phrases, phrases and other.

c. Vocabulary

In writing, it is a must for the writer to choose and use words appropriately in order to avoid unambigious writing. Absolutely the choice of the words, phrases and idioms should be effective.

d. Language Use

It is one of important components to consider. The writer should concern to the rules of grammatical structure such as as tenses, part of speech, subject verb agreement, sentence construction, etc.

e. Mechanics

In mechanics, the writer concerns with the technical rules of writing include the right punctuation, spelling and paragraph.

\section{Recount Text}

Text can be classified into several types. The term of type is sometimes stated as genre. Formally, recount is the sequence text that little more than sequence a series of events. Recount involves the chronological activities which are done in the past time. Recount is also genre competent in writing skill in English curriculum basic competence. Accordingto Knapp and Megan (2005:225) recount text is the simple text in the genre. It should be mastered bystudents in both junior and senior high schoollevel. The socialfuctions of recount are to reconstruct, to record event or activities for the purpose of informing and entertaining. Recount writing focuses on retelling past experiences.

\section{Writing Recount Text}

Writing recount text is focusing on retelling events that happened in the past and telling their sequence series of past events. Three components that must

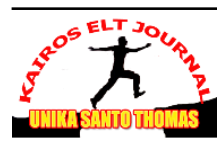


be known in writing recount text are social function, generic structure, and significant lexicogramatical features. Three of them can distinguish one simple genre to another.

Narrative and recount in some ways are similar. It is necessary to discuss narrative and recount to make clear understanding even though the scope of the study is limited to the recount. Both are telling something in the past, so narrative and recount are usually applying past tense; simple past tense, simple past continuous tense or past perpect tense. The ways of narrative and recount told are in chronological order using time or place.

The things that make narrative and recount text are diffrent are structure in which they are constructed. Narrative uses conflicts among the participants whether natural conflicts, social conflicts of psychological conflicts. In some ways narrative text combines all these conflicts. Other contrary, we do not find these conflicts inside recount text. Recount text applies series of events as the basic structure. Knapp and Watkins (2005:201) simple narratives or stories add as major dimension to the structure of a recount. Although narratives have many of the basic features of the recount, textually they a complexity of some sort that must be resolved. Here below is showed the three main elements of recount text.

\section{Think Talk Write Strategy}

Think - Talk - Write is a strategy that facilitating the exercise of language both oral and written fluently. This startegy is based on the interpretation that learning is a social action. TTW is a strategy which was introduced by Huinker and Laughlin (1996:82) state that TTW strategy is intended for the students to think, reflect, and organize the ideas, but these ideas are tested before students are expected to write.

TTW is a learning strategy to train the skills of learners in writing. TTW emphasizes the need for learner to communicate the results of his thinking. Think means using reason to consider and decide something. Talk means speech considerations, thoughts, and opinions. Write means making letters (numbers etc.) with a pen, pencil,chalk, etc. Therefore, the strategy of TTW is a careful planning and action on learning activities, namely through think, talk/discussion, exchange ideas, and write the results of the discussion in order to achieve the expected competence.

At this stage of the talk, the students worked with the group using worksheet (LKS) contains exercises to be done by the students in the group. The importance of talk in learning is able to build an understanding and shared knowledge through interaction and conversation among individuals in the group. Finally, it can provide a solution to the problems faced by leading to an agreement in formulating learning objectives to be achieved. Furthermore, writing phaseis writing the result of the discussion on the worksheets provided.

From the explanations above, it can be concluded that TTW strategy is able to help the students to use and practice the target language being learned in a systematic way.

\section{RESEARCH METHOD}

The research design that will be used in this study is Classroom Action Research (henceforth, CAR). Nunan (1992:229) states that action research is a

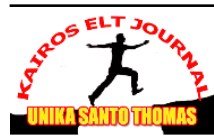


form of self-reflective inquiry carried out by practioner, aimed at solving problems, improving practice, or enchaning understanding. In other words, action research is defined to solve the problems through direct application in the classroom and improving outcomes of teaching and learning. Meanwhile, Mills (2000:6) states that the action research is any systematic inquiry conducted by teacher, researchers, principals school couselors, or other stage holders in teaching or learning environment to gather information about the ways that their particular schools operate, how they teach, and how well their students learn. It means that through the classroom action research, the teacher will know the problem that students face in learning when the teacher gives treatment to the students and evaluate their achievement in learning.

One group test design

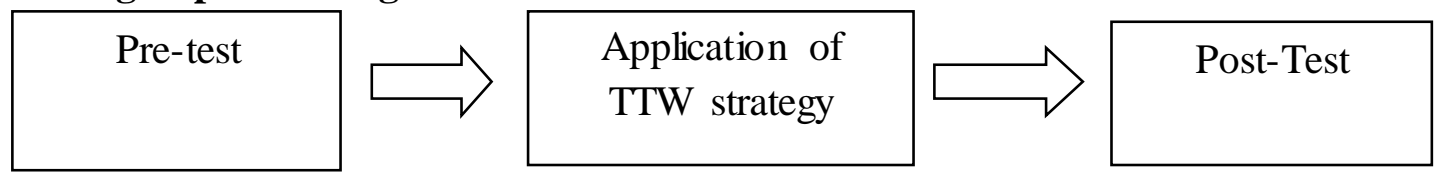

The subject of the study was first given an initial test (pre-test) to determine the extent of the students' initial ability before being given the learning to write using TTW strategy. After being given the initial test, the teacher applies TTW strategy in writing skill. After TTW strategy was applied in writing skill, students were given a final test (post-test) to determine the extent to which students were writing by using TTW strategy.

It can be concluded that classroom action research is an action research in a classroom which can be done by teachers, researchers, and teachers with their colleagues,etc which involves a group of students to improve teaching and learning process or to enhance the understanding of the students to the lesson. A classroom action research will be conducted because it gave the improvement of students' skill. The process in action reserch is shown in the scheme taken from Kemmis and Mc Taggart (1988:11) as follows:

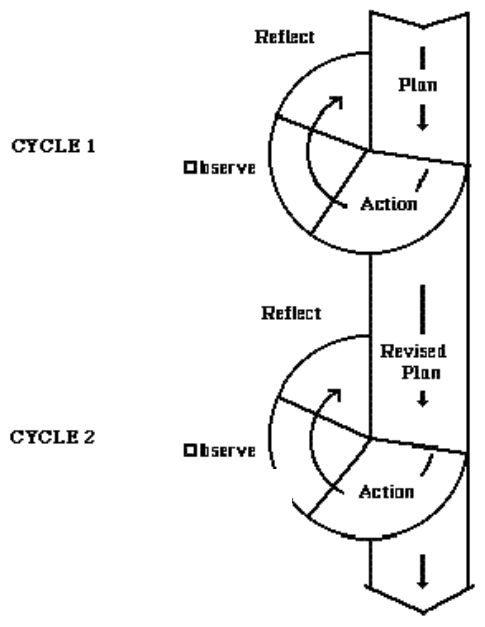

\section{DATA ANALYSIS}

\section{The Data Analysis}

This chapter concerns with the descriptions of data ( before the implementation of the classroom action research, during the implementation of the classroom action research, and after during the implementation of the classroom 
action research) during teaching writing recount text through Think-Talk-Write Strategy.

\section{The Quantitative Data}

The quantitative data was taken from the test result of students, namely pretest before treatment, formative test after cycle one, and post-test after the end of cycle two. The complete result of the students' score in every test can be seen from the table and histogram of score interval and frequency.

From the histogram of the pre-test score interval, the interval from 35-41 and the frequency was $6(16,66 \%)$. Then, interval from $42-48$ and the frequency was $0(0 \%)$. However, the interval from $49-55$ and the frequency was $12(33,33 \%)$. the interval from 56-62 was found 6 as frequency and the percentage was $16,66 \%$. Then, the interval 63-69 was found the percentage 0\%. Finally, the interval score from $70-76$ was found 33,33 as the percentage of the students score of pre-test.

From the histogram of formative test score of percentage the writer found $11,11 \%$ as the interval score formative test was 35-42 and the frequency was 4 . After that, the interval from 43-50 was found the percentage $0 \%$ and the frequency was 0 . Then, the interval from 51-58, and it fell into the 4 frequency was found the percentage $11,11 \%$. Then, the frequency was found 8 and interval was from 59$66(22,22 \%)$. The interval from $75-83$ was found $33,33 \%$ as the percentage and the frequency was 12 . Finally, the interval $83-90$ was found $33,33 \%$ as the percentage and 8 as the frequency.

From the histogram of post-test score interval the writer found $11,11 \%$ interval from 65-69 and the frequency was 4. Then, the interval from 70-74 was found the frequency $0(0 \%)$. Next, the interval from $75-79$ was found the frequency 4 and found $11,11 \%$ as the percentage. Further, the interval from 80-84 was calculated the prcentage $11,11 \%$ and found 4 as the frequency. The frequency score 12 was found on the interval $85-89$, the percentage was 33,33\%. Finally, the writer found 95-99 inerval and the frequency was $8(22,23 \%)$.

Acording to the histogram of quantitative data, the students score increased. The mean score of the students in pre-test was 57,5 and it increased to into 67,2\%. After that, the score of post- test became $83,88 \%$. On the other hand, the median on the pre-test was 50, the formative was 70 and the median of post-test was 95 . Finally, the mode score on the pre-test was 35. It was no longer improved on the formative test 75 . At the end, the mode on the post-test was 85 . Therefore, the score had significanly increased from pre-test to post-test.

The percentage of the students who got the score $\geq 75$ showed the improvement of students' score from the first test (pre-test) until the last (post-test). The histogram above presented that the students' percentage who got score $\geq 75$. There was $16,66 \%$ (6 students) passed KKM in pre-test. In formative test, there was $33,33 \%$ (12 students) passed KKM. Last, in post test, there was 88,88\% (32 students) passed KKM and there were not passed KKM. It can be concluded that there was a significant improvement about $16,66 \%$ until $96,42 \%$ from pre-test to post-test.

\section{The Qualitative Data}

The qualitative data was taken from observation sheet, field notes, and questionnaire and were prsented below.

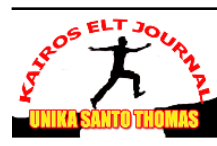




\section{Observation sheet}

Observation sheet was focused on the situation of teaching learning process including the students' activities, behavior and interaction in the classroom. The observation sheet was made by the writer and it checked by the teacher who acted as the collaborator and observed the teaching learning process in the cycle 1 and cycle 2 .

\section{Field Notes}

In this study, the writer also used the field notes as the instrument of collecting the data during the teaching and learning process. The writer observed the activity of thr students during the implementation of Think Talk Write Strategy to improve writing recount text after implementing this strategy. The detail of the process could be seen as follows:

\section{The First Meeting: Monday, Sept $3^{\text {nd }}, 2018$}

In the first meeting, the writer did pre-test before implementing the classroom action research (CAR). It was used to measure the students' writing skill in recount text . it started from 07.15 until $08.00 \mathrm{am}$. In the first meeting, the English teacher and the writer came together to the class. The writer introduced herself and the purpose of the research to the students. Then, the writer called the students name on the attendance list to know how many students present at the day and to get closer to the students. After that, the writer asked the students to make a recount text during 30-40 minutes before treatment and implemented the new strategy that is Thik-Talk - Write Strategy. Therefore, the writer asked the students to write by their own words. After time was over, the writer asked the students to collect their writing text. After the pre-test finished, the writer said thankyou to the students.

\section{The Second Meeting: Wednesday, Sept $5^{\text {th }}, 2018$}

The second meeting was the beginning of cycle I. It started from $10.00 \mathrm{am}$ until $11.45 \mathrm{am}$. The writer opened the class by greeting the students. The chairman lead prayer, and the writer checked the attendance list of the students, after that, the writer prepared the teaching material before starting to teach recount text, and also developed teaching process through the activity of students in the classroom. After that, the writer started to teach recount text based on the problem faced by students toword writing skill in recount text taken from the result of pre-test.

The writer introduced a new strategy in learning recount text, TTW strategy, and started teaching the learning process. The students began to interested in learning because the writer gave them handouts of incomplete recount text. The students were curios about the story in the text. Then, the writer divided the students into nine groups. Then, the writer chose one member in the group to be the leader. After that, the teacher asked them to learn the recount text by putting their opinion , thinking, and then discussion. Then, the writer asked students to write the recount text by using TTW strategy in their group.

\section{The Third Meeting: Monday, Sept $10^{\text {th }}, 2018$}

The third meeting was the second meeting of teaching and learning process in cycle I. It started from 07.15 am until $08.45 \mathrm{am}$. The writer continued the previous material about recount text. Then, the writer reviewed it by asking students one by

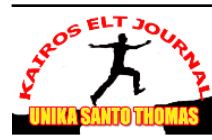


one to prove whether the students still remembered material about what the writer explained the last day. After fhinishing it, the writer continued to explain to the students about the use of $T T W$ strategy in learning writing. After that, the students were also asked to discuss the generic structure of recount text. In the group the students became more enthuasiastic in thinking, discussing, and then writing.

\section{The Fourth Meeting: Wednesday, Sept $12^{\text {th }}, 2018$}

The fourth meeting was the third meeting of teaching learning process in cycle 1 and also the last stage in the CAR for cycle 1. It started from 10.00 am until $10.45 \mathrm{am}$. In this time, the writer gave the second test namely Formative test to the students with topic "Holiday". The writer chose this topic because in writers' opinion that each students must be familiar about text. The writer gave 30-40 minutes to finished.

\section{The Fifth Meeting : Monday, Sept $17^{\text {th }}, 2018$}

The fifth meeting was the first meeting of teaching and learning process in cycle II. It started from 07.15-08.45 am. Based on the result of the formative test in the fourth meeting, the writer gave feedback and appreciation to the students because they had done their best although there were some students still confused about writing aspects and another thing. Therefore, the writer tired to solve the problems by writing a recount text which was still very bad after reviewing on whiteboard. In this time, the writer asked them to be serious on the writers' explanation about the writing aspects of recount texts (organization, content, grammar, vocabulary, spelling, and puctuation).

\section{The Sixth Meeting: Wednesday, Sept $19^{\text {th }}, 2018$}

The sixth meeting was the second meeting of teaching and learning process in cycle II. It started from 10.00until $11.45 \mathrm{am}$. After doing the reflection in the fifth meeting, the writer started the class again with the topic that was "Holiday". In this meeting the writer add the material is past tense. In this meeting the writer gave the students 30 minutes to did the task. After finishing the task, the writer and the students was check their result together. First the writer asked them to mention the past tense inn the text. After that the writer asked the students to make a sentence ano by one from the past tense that they mention before, after the students make a sentence more than six sentences the writer and the students arrange the sentence into paragraph.

\section{The Seventh Meeting: Monday, Sept $24^{\text {th }}, 2018$}

The seventh meeting was the third meeting of teaching and learning process in cycle II. It is started from 07.15 until $08.45 \mathrm{am}$. In this meeting was continued from the las meeting. In this meeting, the writer explained the students TTW Strategy clearly. He students seemed more understand and more avtive and created a good relationship whit their group members. All the students participated in discussing the recount text.

\section{The Eighth Meeting: Wednesday, Sept $26^{\text {th }}, 2018$}

The eighth meeting was the end of the whole cycle in which students were asked to do a test. It started from 07.15 until $08.45 \mathrm{am}$. In this meeting, the writer

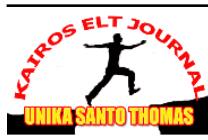


did the last test (post test) to the students. The test was in text from by writing a recount text whith the topic "Unforgetable Experience" with a picturer. It was carried out in 30 until 50 minutes. After that, the writer asked them to collect it. So that the writer could assess and saw the progress of using this strategy. And the end the writer said thankyou and good bye to the students.

\section{Questionnaire}

The questionnaire was conducted after bothof cycle done . from the questionnaire the writer found out the students' respons which were taugh by using TTW Strategy whether it was appropriate with improvement of students' skill in writing recount texts or not. The questionnaire was used to know the students' response toward, TTW Strategy thaat writer applied. The students were asked to give the answer is the category of Strongly Disagree, Disagree, Agree, Strongly Agree.

The first item stated the students like English subject. The result of the questioner showed $21(58,33 \%)$ students strongly agreed with this statement, 12 $(33,33 \%)$ students was agree, $2(5,55 \%)$ students did not quiute agree and $1(2,77 \%)$ disagree. It could be concluded that basically most of them like English Subject.

The second item stated the students are intrested in TTW strategy. 24 $(66,66 \%)$ students srongly agree with the statement. $7(19,44 \%)$ was agreed. 5 $(13,88 \%)$ students disagree . While there was no students who strongly disagree to the first statement. It could be concluded most of students was interesting with this strategy.

The third item ststed that the students enjoyed learning through in TTW Strategy. The result showed $12(33,33 \%)$ students strongly agree,23 $(63,88 \%)$ did not quite agree, $1(2,777 \%)$ disagree, and there was no students who strongly disagree this statement.

The fourth item stated that the use of TTW Strategy makes it easier for students to writing recount texts. $14(38,88 \%)$ students strongly agree, $20(55,55 \%)$ agree, $2(5,55)$ disagree, and there was no students who strongly disagree this statement.

The last item stated that TTW Strategy can help students in English leson. There were $10(27,77 \%)$ students strongly agree, 26(72,22\%) did not quite agree, and there was no students who disagree and strongly disagree this statement. It showed that TTW Strategy was good to be applied in English lesson.

Based on the questionnaire analysis above, the writer conclude that not at also writing a all the students on SMA Santo Yoseph Medan tenth grade students like English subject and also writing a text eveb though some students was disagree like writing and said English in their school was no enjoyable but applying TTW Strategy helped to improve their skill in writing recount text.

\section{Discussion}

TTW strategy was applied to improve the students' writing skill of tenth grade students of SMA Santo Yoseph Medan. The improvement could be seen from the students' mean score the pre-test up to post test. The students ' mean score of pre-test is 57,5, the mean score of formative test is 67,22 and the mean score of post-test is 83,88. As the collaborator, the English teacher and the writer collaboratively discussed the result of the study. They concluded that the use of

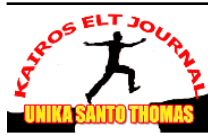


TTW strategy could be effective way to help students in writing skill. The qualitative data also shown that the students became more active, entusiastics in practicing writing skill in the English language.

\section{CONCLUSIONS}

After presenting and analyzing data in the previous chapter, the writer draws the conclusion as follows:

1. The result of the study showed that TTW strategy works effectively on improving students' writing recount text. The improvement could be seen from the stdents' mean score of pre-test, namely 57,5 in formative test namely 67,22 and in post-test namely 83,88 .

2. The students' responses were very good. They felt enthusiastic and motivated after being taught with TTW strategy. It could be seen from the qualitative data such as observation and field notes during the study.

\section{BIBLIOGRAPHY}

Astuti, E,P. 2014. Improving Students' Writing Skill of Recount Texts by Using Think - Talk -Write Strategy at Grade VIII-B of MTS SMQ Bangko. An Unpublished Sarjana's Thesis, Faculty of Language Education Program: State University of Padang.

Brown, H. Douglas. 2001. Teaching by Principles: An Interactive Approach to Language Pedagogy. (Second Edition). San Fransisko: Longman

Gerrot, L and Wignell, P. 1994. Making Sense of Fuctional Grammar. Sydney: Antipodean Educational Enterprises.

Harmer, J. 2004. How to Teach Writing. London: Longman.

Heaton, J.B. 1988. Writing English Language Test. London: Longman.

Hughey, Jane B, et al. 1983. Teaching English Composition: Principles and Technique. Massachusetts: Newbury House.

Huinker, D and Laughlin, C. 1996. Talk Your Way into Writing. Oxford Univers ity.

Hyland, K. 2002. Teaching and Researching Writing: Applied Linguistic in Actions Series. Pearson Education: Longman.

Kemis, S and Robin McTaggart. 1998. The Action Research. Victoria: Daken University.

Knapp, P and Megan, W. 2005. Genre, Test, Grammar: Technologies for Teaching and Assessing Writing. Sydney: University of New South Wales Press. 
KAIROS ELT JOURNAL, Vol. 4 No. 1 April 2020

Copyright@2019, ISSN: 2580-4278

Laksmi, D Vijaya. 2004. Basic Education. New Delhi: Discovery Publishing House.

Mills, Geofrey, E. 2000. Action Research: A Guided for the Teacher. New York: Prentice Hall.

Nunan, D. 1992. Research Methods in Language Teaching. New York: Cambridge University Press.

Wallace, Michael. J. 1998. Action Research for Language Teacher. Cambridge: Cambridge University Press.

Waryanti, S. 2016. The Implementation of Think - Talk - Write Strategy to Improve the Students' Achievement in Writing Recount Texts among the Eighth Grade Students of SMP Negeri 1

Wates in the Academic Year 2016/2017. An Unpublished Sarjana's Thesis, Faculty of Languages and Arts State University of Yogyakarta.

Weigle, S.C. 2002. Assessing Writing. Cambridge : Cambridge University Press. 